\title{
КВАНТИТАТИВНІ ХАРАКТЕРИСТИКИ ПОРЯДКУ СЛІВ У СУЧАСНІЙ УКРАЇНСЬКІЙ РОЗМОВНІЙ МОВІ (на матеріалі односкладних дієслівних речень)
}

Мета статті - установити поширеність порядку слів різних типів у сучасній українській розмовній мові. Джерела дослідження - тексти п'єс сучасних українських авторів і тексти приватного листування. Отримані дані свідчать про те, що загалом переважають односкладні речення й приєднувальні конструкції зі структурою Р та РО. Усі синтаксичні одиниці поділено на дві групи залежно від засобу вираження в них головного члена. Виявлено, що кількісну перевагу мають речення й приєднувальні конструкції, головний член яких виражений дієвідмінюваним або безособовим дієсловом. Особливу увагу зосереджено на змінах порядку слів залежно від жанрових різновидів розмовного стилю. З'ясовано, що в текстах різних жанрів трапляється різний порядок слів.

Ключові слова: розмовний стиль, порядок слів, односкладні дієслівні речення, париеляти, приєднувальні конструкиії.

Shukhova O. Quantitative Characteristics of Word Order in Modern Ukrainian Colloquial Language (Based on the Material of Single-Constituent Verbal Clauses). The article investigates the frequency of different types of word order in modern Ukrainian colloquial language. The topicality of the research is connected with the absence of investigations of word order in different registers of Ukrainian in modern linguistics. The aim of the article is to find out the occurrence of different types of word order in modern Ukrainian colloquial language. To reach this aim the following objectives have been set: to give the statistics of the occurrence of different word order in single-constituent verbal clauses, to analyse the changes of word order depending on the genre of the colloquial language. The sources of the research are texts of plays written by modern Ukrainian authors and texts of private letters. With the help of the method of total sampling 1172 single-constituent syntactical units and 140 conjunctive constructions have been excerpted. The descriptive method has made it possible to systematize the syntactical units, to classify them according to the way their nucleus is expressed, to find out the peculiarities of word order depending on the genre of the colloquial language. With the help of the quantitative method it has been established that the single-constituent clauses and conjunctive constructions which correspond to the structure $P(29,5 \% ; 16,4 \%)$ and $P O(17,3 \% ; 15,7 \%)$ are on the whole the most common. The investigation has proved that the single-constituent clauses and conjunctive constructions the nucleus of which is expressed by means of finite forms of the verb are predominant (78,2\%;67,1\%). Among them the word 
order $P(33 \% ; 19,1 \%), P O(17,3 \% ; 13,8 \%)$ is the most common. The syntactical units with the nucleus expressed by non-finite verb forms are not frequent. It has been found out that various types of word order occur in texts of different genres. In order to make the results of the investigation more illustrative we have organised them into six tables. Taking into account the absence of works devoted to the above-mentioned problem, the future prospect of our investigation is to find out the frequency of word order in other registers of modern Ukrainian.

Key words: colloquial language, word order, single-constituent verbal clauses, parcels, conjunctive constructions.

\section{Вступ}

Порядок слів здавна привертає увагу світових, зокрема й українських, мовознавців. Студії, присвячені розташуванню слів у реченні, $є$ численними, проте багато питань і до наших днів залишаються поза увагою дослідників. Відсутність у сучасному українському мовознавстві спеціальних досліджень порядку слів у різних функціональних стилях зумовила актуальність поданої наукової розвідки. Серед сучасних українських мовознавців проблеми розташування слів у словосполученні й реченні торкаються А. Й. Багмут (Багмут, 2007), С. П. Бевзенко (Бевзенко, 2005), С. Я. Єрмоленко (Єрмоленко, 2001), досліджуючи типи словопорядку й деякі його функціі. Праці C. I. Дорошенка (Дорошенко, 2006), А. П. Загнітка (Загнітко, 2001), В. В. Орєхова (Орєхов, 2010) присвячені взаємозв'язку порядку слів і актуального членування речення. Метою пропонованого дослідження $€$ встановлення поширеності різних типів словопорядку в розмовному стилі сучасної української мови. Для досягнення мети було поставлено такі завдання: подати статистичні дані щодо поширеності того чи того порядку слів в односкладних реченнях, проаналізувати зміни порядку слів залежно від жанрових різновидів розмовного стилю. Матеріалом дослідження стали односкладні дієслівні речення, дібрані з текстів п’єс сучасних українських авторів і текстів приватного листування.

\section{Методи та методики дослідження}

У процесі дослідження для отримання корпусу односкладних речень було використано метод суцільної вибірки. За допомогою описового методу систематизовано дібрані синтаксичні одиниці, проаналізовано їх структуру, класифіковано за способом вираження головного члена в них, встановлено особливості порядку слів залежно 
від засобів вираження головного члена й жанрових різновидів розмовного стилю. Прийоми квантитативного методу використано для надання статистичних даних щодо поширеності того чи того порядку слів в односкладних реченнях.

\section{Результати та дискусії}

Проаналізовано 1172 односкладних речення й 140 приєднувальних конструкцій, що являють собою сурядні або підрядні частини складних речень, інтонаційно оформлені як окремі речення й мають певну структурно-граматичну автономність.

Н. В. Новохатська зазначає, що в сучасній мовознавчій науці актуальною залишається проблема розмежування явищ парцеляції й приєднання, адже існують два підходи до вирішення цієї проблеми: універсально-індивідуальний, що вивчає природу парцеляції й приєднання крізь призму тотожності або індивідуальності, і диференційний, що полягає в розгляді парцеляції й приєднання як окремих синтаксичних конструкцій (Новохатська, 2013: 303-304). Зважаючи на дефініції обох понять, запропонованих ученими, надалі іменуємо такі синтаксичні одиниці приєднувальними конструкціями, хоча відсутність чітко визначених критеріїв для їхнього розмежування не виключає можливості віднесення деяких з них і до парцелятів.

У таблиці 1 представлено загальну кількість односкладних речень і приєднувальних конструкцій різних типів, дібраних з текстів сучасних п’єс і текстів приватного листування.

Таблиця 1

\begin{tabular}{|l|c|c|c|c|}
\hline \multicolumn{1}{|c|}{ Тип речень } & $\begin{array}{c}\text { Кількість } \\
\text { речень }\end{array}$ & $\begin{array}{c}\text { \% від кільк. } \\
\text { реч. }\end{array}$ & $\begin{array}{c}\text { Кількість } \\
\text { приєдн. } \\
\text { констр. }\end{array}$ & $\begin{array}{c}\text { \% від кільк. } \\
\text { приєдн. } \\
\text { констр. }\end{array}$ \\
\hline Всього & 1172 & & 140 & 58,6 \\
\hline Озн.-особові & 824 & 70,3 & 82 & 6,4 \\
\hline Неозн.-особ. & 49 & 4,2 & 9 & - \\
\hline Узаг.-особові & 2 & 0,2 & - & 25 \\
\hline Безособові & 214 & 18,3 & 35 & 10 \\
\hline Інфінітивні & 83 & 7,1 & 14 & \\
\hline
\end{tabular}

У таблиці 2 відображено поширеність різних типів порядку слів в односкладних реченнях і приєднувальних конструкціях. Для позначення членів речення використано такі скорочення: $\mathrm{P}$ - головний член односкладного речення, О - додаток, С - обставина. 
Таблиця 2

\begin{tabular}{|c|c|c|c|c|c|c|c|c|c|}
\hline $\begin{array}{l}\text { Пор. } \\
\text { слів }\end{array}$ & $\begin{array}{c}\text { Кільк. } \\
\text { реч. }\end{array}$ & $\begin{array}{c}\% \text { від } \\
\text { кільк. } \\
\text { реч. }\end{array}$ & $\begin{array}{c}\text { Кільк. } \\
\text { приєд. } \\
\text { конст. }\end{array}$ & $\begin{array}{c}\text { \% від } \\
\text { кіл. пр. } \\
\text { конст. }\end{array}$ & $\begin{array}{l}\text { Пор. } \\
\text { слів }\end{array}$ & $\begin{array}{c}\text { Кільк. } \\
\text { реч. }\end{array}$ & $\begin{array}{c}\% \text { від } \\
\text { кільк. } \\
\text { реч. }\end{array}$ & $\begin{array}{c}\text { Кільк. } \\
\text { приєд. } \\
\text { конст. }\end{array}$ & $\begin{array}{c}\text { \% від } \\
\text { кіл. } \\
\text { пр. } \\
\text { конст. }\end{array}$ \\
\hline $\mathrm{P}$ & 346 & 29,5 & 23 & 16,4 & COP & 18 & 1,5 & 5 & 3,6 \\
\hline $\mathrm{PO}$ & 203 & 17,3 & 22 & 15,7 & PCO & 15 & 1,3 & - & - \\
\hline OP & 116 & 9,9 & 13 & 9,3 & $\mathrm{CPC}$ & 14 & 1,2 & - & - \\
\hline $\mathrm{CP}$ & 83 & 7,1 & 10 & 7,1 & OCP & 13 & 1,1 & 9 & 6,4 \\
\hline POO & 78 & 6,7 & 5 & 3,6 & OPC & 12 & 1 & 5 & 3,6 \\
\hline $\mathrm{PC}$ & 63 & 5,4 & 5 & 3,6 & POOO & 12 & 1 & - & - \\
\hline $\mathrm{CPO}$ & 32 & 2,7 & 3 & 2,1 & Інші & 102 & 8,7 & 33 & 23,6 \\
\hline POC & 25 & 2,1 & - & - & $\begin{array}{c}\text { Розп. } \\
\text { неокл. } \\
\text { окл. }\end{array}$ & $\begin{array}{c}647 \\
560 \\
87\end{array}$ & $\begin{array}{c}55,2 \\
47,8 \\
7,4 \\
\end{array}$ & $\begin{array}{c}66 \\
57 \\
9\end{array}$ & $\begin{array}{c}47,1 \\
40,7 \\
6,4 \\
\end{array}$ \\
\hline $\mathrm{OPO}$ & 22 & 1,9 & 4 & 2,9 & $\begin{array}{c}\text { Пит. } \\
\text { Пит.- } \\
\text { окл. }\end{array}$ & $\begin{array}{c}141 \\
3\end{array}$ & $\begin{array}{c}2 \\
0,3\end{array}$ & $\begin{array}{c}27 \\
1\end{array}$ & $\begin{array}{c}19,3 \\
0,7\end{array}$ \\
\hline OOP & 18 & 1,5 & 3 & 2,1 & $\begin{array}{c}\text { Спон. } \\
\text { неокл. } \\
\text { окл. }\end{array}$ & $\begin{array}{c}381 \\
287 \\
94 \\
\end{array}$ & $\begin{array}{c}32,5 \\
24,5 \\
8\end{array}$ & $\begin{array}{c}46 \\
39 \\
7\end{array}$ & $\begin{array}{c}32,6 \\
27,9 \\
5\end{array}$ \\
\hline
\end{tabular}

Наведені дані свідчать про те, що загалом в односкладних дієслівних реченнях найпоширенішим є порядок слів Р і РО - Ходімо... (Н. Неждана); Дякую за каву (А. Багряна). Перевагу цих типів порядку слів спостерігаємо й у приєднувальних конструкціях: - Однак будемо реалістами (О. Миколайчук-Низовець); I не відключай телефон (Лист матері до 15-річної доньки).

У проаналізованому матеріалі спостерігаємо кількісну перевагу розповідних і спонукальних синтаксичних одиниць. Таблиці 3 й 4 надають інформацію щодо поширеності порядку слів у них.

Таблиця 3

\begin{tabular}{|c|c|c|c|}
\hline Розпов. & $\begin{array}{l}\text { Найпоширен. } \\
\text { порядок слів }\end{array}$ & $\begin{array}{c}\text { \% від кільк. } \\
\text { реч./ пр.конст. }\end{array}$ & Приклад \\
\hline а) неокл. & $\mathrm{P} ; \mathrm{OP} / \mathrm{P} ; \mathrm{CP}$ & 23,$7 ; 17 / 12,3 ; 12,3$ & $\begin{array}{l}\text { Дякую (П. Ар’є); Від брейк-дансу } \\
\text { звільняєшся (Н. Неждана) / І зна- } \\
\text { ти не хочу (П. Ар'є); Але ж так } \\
\text { годиться (Н. Неждана). }\end{array}$ \\
\hline б) окл. & $\mathrm{P} ; \mathrm{PO} / \mathrm{P}$ & 48,$3 ; 13,8 / 33$ & $\begin{array}{l}\text { Захоплююсь! (Н. Неждана); } \\
\text { Женіть ї̈! (А. Багряна) / I про- } \\
\text { щай! (Прощ. лист до хлопця) }\end{array}$ \\
\hline
\end{tabular}


Шухова О. О. Квантитативні характеристики порядку слів у сучасній українській розмовній мові...

Таблиця 4

\begin{tabular}{|c|c|c|c|}
\hline Спонук. & $\begin{array}{c}\text { Найпоширен. } \\
\text { порядок слів }\end{array}$ & $\begin{array}{c}\text { \% від кільк. } \\
\text { реч./ пр.конст. }\end{array}$ & Приклад \\
\hline a) неокл. & $\begin{array}{l}\mathrm{PO} ; \mathrm{P} / \\
\mathrm{PO} ; \mathrm{P}\end{array}$ & $\begin{array}{l}30,3 ; 28,9 / \\
28,2 ; 23,1\end{array}$ & $\begin{array}{l}\text { Тримай ліхтарика (Н. Неждана); Пере- } \\
\text { стань (А.Багряна) / I, взагалі, облиште } \\
\text { мій парашут (Н. Неждана); А все-таки } \\
\text { спробуй (Н. Неждана). }\end{array}$ \\
\hline б) окл. & $\begin{array}{l}\mathrm{P} ; \mathrm{PO} / \\
\mathrm{P} ; \mathrm{PO}\end{array}$ & $\begin{array}{l}39,4 ; 23,4 / \\
42,9 ; 28,6\end{array}$ & $\begin{array}{l}\text { Не ображайся! (Прощ. лист до хлопця); } \\
\text { Не заплутуйте мене! (Н. Неждана) / } \\
\text { А поговорити! (О. Миколайчук-Низо- } \\
\text { вець); I не мрій про більше! (А. Багряна) }\end{array}$ \\
\hline
\end{tabular}

Усі синтаксичні одиниці функції поділено на дві групи. До першої відносимо речення й приєднувальні конструкції з головним членом, вираженим дієвідмінюваним або безособовим дієсловом. Виділено 917 речень і 94 приєднувальних конструкції цього типу, що складає 78,2 \% й 67,1 \% відповідно. Серед них найчастіше трапляється порядок слів Р (33\%; 19,1 \%) - Закури (П. Ар'є); I не подумаю (Н. Неждана) й $\mathrm{PO}(17,3 \% ; 13,8$ \%) - Не чіпайте мою ногу! (Н. Неждана); I не забувай моїх дружніх порад (А. Багряна).

До другої групи відносимо синтаксичні одиниці з головним членом, до складу якого входять невідмінювані форми дієслова (255 речень, 46 приєднувальних конструкцій).

Дібрано 250 речень і 45 приєднувальних конструкцій з інфінітивом. У 37,2 \% / 42,2 \% випадків інфінітив входить до складу головного члена речення в комбінації з дієвідмінюваним або безособовим дієсловом: - Ще полюбляю малювати фарбами та олівиями (Перші дитячі листи до «Резиденції Святого Миколая»); I навіть не намагайся мене знайти (Лист скривдженого чоловіка своїй дружині). У 23,6 \% / 28,7 \% випадків інфінітив у комбінації з модальним дієсловом утворює безособові речення: - Нею навіть можна насолоджуватися (Лист бабусі новонародженій онуці); А може, вам не треба сюди нагороди приносити (П. Ар'є). На відміну від більшості вчених, таких як П.С. Дудик (Дудик, 1972: 253-254), К.Ф. Шульжук (Шульжук, 2004: 125-127) та ін., які відносять ці речення до безособових, I.Р. Вихованець вважає такі синтаксичні одиниці інфінітивними (Вихованець, 1993: 99). А.П. Загнітко (Загнітко, 2001: 207) називає їх безособовоінфінітивними, наголошуючи на поєднанні в них ознак обох типів. 18,4 / 28,9 \% становлять синтаксичні одиниці, у яких інфінітив виконує функцію головного члена самостійно: - Як би тобі сказати... 
(О. Миколайчук-Низовець); Але не загострювати увагу на иььму! (Прощальний лист до хлопця). У 16,4 \% / 4,4 \% інфінітив виступає в комбінації з іменною частиною мови: - Мене звати Сергій (Лист до Діда Мороза); А старшу звати Таня (Лист до Святого Миколая). 3,6 \% становлять речення, до складу головного члена яких інфінітив входить разом $з$ дієвідмінюваним чи безособовим дієсловом й іменною частиною мови - Захотілося стати дурепою (Лист в нікуди).

У 5 реченнях та 1 приєднувальній конструкції головний член виражений предикативною формою на -но, -то, що деякою мірою $є$ подібною до дієприкметника (Вихованець, 2004: 222). Усі дібрані синтаксичні одиниці мають різний порядок слів; предикативна форма на -но, -то виконує функцію головного члена без лексично вираженої дієслівної зв'язки бути; вказівки на виконавця дії або знаряддя немає: - Живий вогонь заборонено за правилами безпеки (Н. Неждана); Хоч то у нас в Повстанській армї заборонено не вірити (П. Ар'є).

3 урахуванням поділу речень залежно від засобу вираження головного члена надалі здійснено спробу встановити поширеність порядку слів залежно від жанрових різновидів розмовного стилю. Л. І. Мацько (Мацько, 2005: 291) зазначає, що, окрім усної форми, нині розмовний стиль поширюється й у писемній формі (епістоляpiї, художні твори). О. Є. Чуєшкова (Чуєшкова, 2011: 97-98), С. Я. Єрмоленко (Єрмоленко, 2007: 675-676), А. П. Коваль (Коваль, 1987: 13) вказують на те, що не всі стилісти визнають епістолярний стиль, вважаючи його різновиди (офіційний і приватний) сферою офіційно-ділового та розмовного стилів. Зважаючи на це, до нашого аналізу було залучено тексти п’єс сучасних українських авторів та тексти сучасного приватного листування, дібрані з мережі Інтернет.

Таблиця 5 відображує поширеність словопорядку в синтаксичних одиницях з головним членом, вираженим дієвідмінюваним або безособовим дієсловом.

Таблиця 5

\begin{tabular}{|c|c|c|c|c|}
\hline & $\begin{array}{l}\text { Кільк. реч. / } \\
\text { приєд. конст. }\end{array}$ & $\begin{array}{l}\text { Найпошир. } \\
\text { пор. слів }\end{array}$ & $\begin{array}{l}\text { \% від кільк. } \\
\text { реч. / пр.конс. }\end{array}$ & Приклад \\
\hline П’єси & $539 / 61$ & $\mathrm{P} / \mathrm{P}$ & $44,5 / 23$ & $\begin{array}{l}\text { Не знаю (Н. Неждана) / } \\
\text { I піду (Н. Неждана). }\end{array}$ \\
\hline $\begin{array}{l}\text { Прив. } \\
\text { лист. }\end{array}$ & $378 / 33$ & $\begin{array}{c}\mathrm{PO} / \\
\mathrm{P} ; \mathrm{POO}\end{array}$ & $\begin{array}{c}21,7 / \\
12,1 ; 12,1\end{array}$ & $\begin{array}{l}\text { Допомагаю батькам (Лист } \\
\text { до Діда Мороза) / I пробач (Лист } \\
\text { прощання); Тому принеси мені } \\
\text { велосипед (Лист до Св. Миколая) }\end{array}$ \\
\hline
\end{tabular}


Шухова О. О. Квантитативні характеристики порядку слів у сучасній українській розмовній мові...

Таблиця 6 надає інформацію щодо поширеності порядку слів у синтаксичних одиницях з головним членом, до складу якого входить інфінітив.

Таблиця 6

\begin{tabular}{|c|c|c|c|l|}
\hline & $\begin{array}{c}\text { Кільк. реч. / } \\
\text { приєд. конст. }\end{array}$ & $\begin{array}{c}\text { Найпошир. } \\
\text { пор. слів }\end{array}$ & $\begin{array}{c}\text { \% від кільк. } \\
\text { реч. / пр. конс. }\end{array}$ & \multicolumn{1}{|}{ Приклад } \\
\hline П’єси & $121 / 23$ & $\begin{array}{c}\text { Р; РО / } \\
\text { ОСР }\end{array}$ & $\begin{array}{c}\text { Треба розтерти ... (Н. Не- } \\
\text { ждана); Хочете } \\
\text { перенести операцію? } \\
\text { (П. Ар'є) / I щзо ж тут } \\
\text { можна палити? (Н. Неждана) }\end{array}$ \\
\hline $\begin{array}{c}\text { Прив. } \\
\text { лист. }\end{array}$ & $129 / 22$ & ОР / РО & $35 / 31,8$ & $\begin{array}{l}\text { Иого можна оперувати } \\
\text { (П. Ар'є) / А хочеться } \\
\text { бути з ним (Лист в нікуди). }\end{array}$ \\
\hline
\end{tabular}

\section{Висновки}

Таким чином, серед односкладних дієслівних речень і приєднувальних конструкцій поширені речення, що відповідають структурі $\mathrm{P}$ й РО. Односкладні речення, головний член яких виражений дієвідмінюваним або безособовим дієсловом, $є$ найчисленнішими. Установлено, що в текстах різних жанрів трапляється різний порядок слів. Перспектива подальшого дослідження вбачається у вивченні порядку слів в інших функціональних стилях сучасної української мови.

\section{ЛІТЕРАТУРА}

1. Багмут А. Й. Порядок слів. Украӥнська мова. Енциклопедія / редкол: Русанівський В. М., Тараненко О. О. (співголови), Зяблюк М.П. та ін. 3-є вид., зі змінами і доп. Київ: Українська енциклопедія ім. М. П. Бажана, 2007. С. 529. 2. Бевзенко С. П., Литвин Л. П., Семеренко Г. В. Сучасна українська мова. Синтаксис: навч. посіб. Київ: Вища школа, 2005. 270 с. 3. Вихованець I. Р. Граматика української мови. Синтаксис: підруч. Київ: Либідь, 1993. 368 с. 4. Вихованець І., Городенська К. Теоретична морфологія української мови. Київ: Унів. вид-во «Пульсари», 2004. 400 с. 5. Дорошенко C. I. Загальне мовознавство: навч. посіб. Київ: Центр навчальної літератури, 2006. 288 с. 6. Дудик П. С. Односкладні речення. Сучасна українська літературна мова в 5-ти кн. Синтаксис / за заг. ред. акад. І.К. Білодіда. Київ: Наукова думка, 1972. Кн. 3. С. 232-262. 7. Єрмоленко С. Я. Стиль. Украйнська мова. Енциклопедія / редкол.: Русанівський В. М., Тараненко О. О. (співголови), Зяблюк М. П. та ін. 3-є вид., зі змінами і доп. Київ: «Українська енциклопедія ім. М.П. Бажана», 2007, С. 675676. 8. Єрмоленко С. Я., Бибик С. П., Тодор О. Г. Порядок слів. Українська мова. Короткий тлумачний словник тінгвістичних термінів / за ред. С.Я. Єрмоленко. Київ: Либідь, 2001. С. 133-134. 9. Загнітко А. П. Теоретична граматика української мови. 
Синтаксис: монографія. Донецьк ДонНУ, 2001. 662 с. 10. Коваль А. П. Практична стилістика сучасної української мови: підруч. 3-є вид., доп. і переробл. Київ: Вища школа, 1987. 351 с. 11. Мацько Л. І., Сидоренко О. М., Мацько О. М. Стилістика української мови: підруч. / за ред. Л. І. Мацько. 2-ге вид. Київ: Вища школа, 2005. 462 с. 12. Новохатська Н. В. Приєднання й парцеляція як засоби формального членування англійських та українських розмовних структур. Проблеми семантики, прагматики та когнітивної лінгвістики. Київ: КНУ ім. Тараса Шевченка, 2013. Вип. 23. С. $303-$ 309. 13. Орєхов В. В. Актуальне членування речення, його статус в лінгвістичній системі. Вісник Маріупольського державного університету. Серія: Філологія. Маріуполь, 2010. № 2 (4). С. 157-163. 14. Чуєшкова О. Є. Епістолярний стиль. Українська мова. Енциклопедія / за ред. I. В. Муромцева. Київ: Майстер-клас, 2011. С. 97-98. 15. Шульжук К. Ф. Синтаксис української мови: підруч. Київ: ВЦ «Академія», 2004. 408 с.

\section{REFERENCES}

1. Bahmut, A. I. (2007). Poriadok sliv [Word order]. Ukrainska mova. Entsyklopediia Ukrainian. Encyclopedia (3rd ed., rev.). Kyiv: Ukrainska entsyklopediia im. M.P. Bazhana [in Ukrainian]. 2. Bevzenko, S. P., Lytvyn, L. P., Semerenko, H. V. (2005). Suchasna ukrainska mova. Syntaksys [Modern Ukrainian. Syntax]. Kyiv: Vyshcha shkola [in Ukrainian]. 3. Vykhovanets, I. R. (1993). Hramatyka ukrainskoi movy. Syntaksys [Grammar of Ukrainian. Syntax]. Kyiv: Lybid [in Ukrainian]. 4. Vykhovanets, I. \& Horodenska, K. (2004). Teoretychna morfolohiia ukrainskoi movy [Theoretical morphology of Ukrainian]. Kyiv: Pulsary [in Ukrainian]. 5. Doroshenko, S. I. (2006). Zahalne movoznavstvo [General linguistics]. Kyiv: Tsentr navchalnoi literatury [in Ukrainian]. 6. Dudyk, P. S. (1972) Odnoskladni rechennia [Single-constituent clauses]. Suchasna ukrainska literaturna mova. Syntaksys - Modern literary Ukrainian. Syntax. (Vol. 3). Kyiv: Naukova dumka [in Ukrainian]. 7. Yermolenko, S. Ia. (2007) Styl [Style]. Ukrainska mova. Entsyklopediia - Ukrainian. Encyclopedia (3rd ed., rev.). Kyiv: Ukrainska entsyklopediia im. M. P. Bazhana [in Ukrainian]. 8. Yermolenko, S. Ia., Bybyk, S. P. \& Todor, O. H. (2001) Poriadok sliv [Word order]. Ukrainska mova. Korotkyi tlumachnyi slovnyk linhvistychnykh terminiv - Ukrainian. Brief explanatory dictionary of linguistic terms. Kyiv: Lybid [in Ukrainian]. 9. Zahnitko, A. P. (2001). Teoretychna hramatyka ukrainskoi movy. Syntaksys [Theoretical Grammar of Ukrainian. Syntax]. Donetsk: DonNU [in Ukrainian]. 10. Koval, A. P. (1987). Praktychna stylistyka suchasnoi ukrainskoi movy [Practical stylistics of modern Ukrainian] (3rd ed., rev.). Kyiv: Vyshcha shkola [in Ukrainian]. 11. Matsko, L. I., Sydorenko, O. M. \& Matsko, O. M. (2005). Stylistyka ukrainskoi movy [Stylistics of Ukrainian] (2nd ed., rev.). Kyiv: Vyshcha shkola [in Ukrainian]. 12. Novokhatska, N. V. (2013) Pryiednannia y partseliatsiia yak zasoby formalnoho chlenuvannia anhliiskykh ta ukrainskykh rozmovnykh struktur [Adjunction and parceling as means of formal division of English and Ukrainian conversational structures]. Problemy semantyky, prahmatyky ta kohnityvnoi linhvistyky - Problems of semantics, pragmatics and cognitive linguistics]. Kyiv: KNU im. Tarasa Shevchenka, 23, 303-309 [in Ukrainian]. 13. Oriekhov, V. V. (2010). Aktualne chlenuvannia rechennia, yoho status v linhvistychnii systemi [Actual division of the sentence, its status in linguistic system]. Visnyk Mariupolskoho derzhavnoho universytetu. Seriia: Filolohiia - Bulletin of Mariupol State University. Ser: Philology, 2 (4), 
157-163 [in Ukrainian]. 14. Chuieshkova, O. Ie. (2011) Epistoliarnyi styl. [Epistolary register]. Ukrainska mova. Entsyklopediia. - Ukrainian. Encyclopedia. Kyiv: Maister-klas [in Ukrainian]. 15. Shulzhuk, K. F. (2004) Syntaksys ukrainskoi movy [Syntax of Ukrainian]. Kyiv: VTs «Akademiia» [in Ukrainian].

Шухова Оксана Олександрівна - викладач кафедри англійської фонетики і граматики, Харківський національний педагогічний університет імені Г.С. Сковороди; вул. Валентинівська, 2, м. Харків, 61168, Україна.

Tel.: +38-095-325-35-24

E-mail: oksanashukhova@gmail.com, accent-ch@ukr.net http://orcid.org/0000-0002-5126-6728

Shukhova Oksana - Lecturer, English Phonetics and Grammar Department, H.S. Skovoroda Kharkiv National Pedagogical University; Valentynivska Str. 2, Kharkiv, 61168, Ukraine.

Надійшла до редакції 07 лютого 2020 року 